\title{
Hepatorenal Sendrom Tanısı Olan Bireylerde Hemşirelik Bakımı
}

\author{
Nursing Care in Individuals with \\ Hepatorenal Syndrome
}

\author{
Pınar ONGÜN ${ }^{1}$, İnci KIRTIL ${ }^{2}$, Seher Deniz ÖZTEKİN ${ }^{3}$
}

${ }^{l} \ddot{O g}$ r. Gör.- Balıkesir Üniversitesi Sağlı Bilimleri Fakültesi Hemşirelik Bölümü, Balıkesir, Türkiye

${ }^{2}$ Arş. Gör.- Marmara Üniversitesi Sağllk Bilimleri Fakültesi Hemşirelik Bölümü, Cerrahi Hastalıkları

Hemşireliği AD, İstanbul, Türkiye

${ }^{3}$ Prof.Dr.- İstanbul Üniversitesi- Cerrahpaşa, Florence Nightingale Hemşirelik Fakültesi, Cerrahi Hastalikları

Hemşireliği AD, İstanbul, Türkiye

* Bu çalışma 3-6 Ekim 2019 tarihinde Çeşme'de gerçekleştirilen, 3.Uluslararası 11.Ulusal Türk Cerrahi ve Ameliyathane Hemşireliği Kongresi'nde poster bildiri olarak sunulmuştur.

Geliş Tarihi / Received :

13 Ağustos/Aug 2020

Kabul Tarihi / Accepted:

25 Ocak/Jan 2021

\section{İletişim yazarı / \\ Correspondence author}

Pınar ONGÜN

E-posta: pinar.ongun@yahoo.com

\section{ORCID}

Pınar ONGÜN

0000-0003-2935-7583

İnci KIRTIL

0000-0002-1731-5282

Seher Deniz ÖZTEKIN

0000-0001-5215-7913

\section{Özet}

Hepatorenal sendrom, karaciğer yetmezliği olan hastalarda görülen en yaygın komplikasyonlardan biridir. Azotemi, oligüri, glomerüler filtrasyon hızının azalması ve inatçı assitin artmasıyla ortaya çıkan böbrek yetmezliği tablosudur. Böbreklerde yapısal bir sorun yoktur. Hepatorenal sendrom oluşumuna portal hipertansiyon, splenik arteriyel vazodilatasyon sebep olur. Sonuç olarak, renal hipoperfüzyona neden olan renal vazokonstrüksiyon gelişir. Karaciğer transplantasyonu gerçekleşen hastalarda ameliyat sırasındaki yetersiz perfüzyona bağlı gelişen akut tübüler nekroz, ameliyat sonrası hipovolemi ve ilaçlara bağlı gelişen nefrotoksisite, karaciğer nakli sonrası böbrek yetmezliğinin diğer önemli nedenlerindendir. Tedavide amaç, splenik ve sistemik vazokonstrüksiyonun düzeltilmesi, böbreklerin vazodilatasyonunun sağlanması ve sodyum dengesi ile birlikte normovoleminin sağlanmasıdır. Hemşirelik bakımında; klinikte hastanın hemodinamisinin stabil olması sağlanmalı, laboratuvar bulguları izlenmeli ve hastanın durumu sıklıkla değerlendirilmelidir. Ayrıca hasta sıv1-elektrolit dengesizlikleri yönünden izlenmelidir. Hepatorenal sendroma bağlı olarak hastanın saatlik diürez miktarı, ortalama arter basıncı, kreatinin klirensi ve serum kreatin gibi kritik değerlerindeki ani değişimler, su ve tuz tutulumuna bağlı olarak ortaya çıkan ödem hastanın hemodinamisinin olumsuz etkilenmesine neden olur. Özellikle yoğun bakım ünitelerinde hastaların izlemi önem taşımaktadır.

Anahtar kelimeler: Hepatorenal sendrom; Böbrek yetmezliği; Hemşirelik bakımı. 


\begin{abstract}
Hepatorenal syndrome is one of the most common complications seen in patients with liver failure. Azotemia, oliguria, decreased glomerular filtration rate, and renal failure manifested by increased persistent acidity. There is no structural problem in the kidneys. Portal hypertension and splenic arterial vasodilation cause the formation of hepatorenal syndrome. As a result, renal vasoconstriction causes of renal hypoperfusion. Acute tubular necrosis due to inadequate perfusion during surgery, postoperative hypovolemia, and drug-induced nephrotoxicity in patients with liver transplantation are other important causes of renal failure after liver transplantation. To correct splenic and systemic vasoconstriction, to provide vasodilatation of the kidneys, and to provide normovolemia with sodium balance are the treatment aims. In nursing care; In the clinic, the patient's hemodynamics should be stabilized, laboratory findings should be monitored and the patient's condition should be evaluated frequently. Also, the patient should be monitored in terms of fluid-electrolyte imbalances. Sudden changes in critical values such as the patient's urine output, mean arterial pressure, creatinine clearance and serum creatinine due to hepatorenal syndrome, edema due to water and salt retention cause the patient's hemodynamics to be negatively affected. Monitoring of patients is important, especially in intensive care units.
\end{abstract}

Keywords: Hepatorenal syndrome; Kidney failure; Nursing care.

\section{GİRIŞ}

Hepatorenal sendrom (HRS), sirozlu hastalarda sıklıkla görülen, karaciğer yetmezliği ile birlikte seyreden, genellikle kötü prognozu gösteren, işlevsel olarak geri döndürülebilir böbrek yetmezliği tablosudur (1-5). İnsidans belirlemeye yönelik yapılan bir araştırmada, böbrek hasarı gelişen sirozlu hastaların \%23,9'unda HRS görüldügü bildirilmiştir (6). Yoğun bakıma kabul edilen sirozlu hastaların incelendiği bir çalışmada hastaların \%73,1'inde akut böbrek hasarı (ABH) saptanmıştır. ABH saptanan bu hastalarda en yaygın görülen komplikasyonlar; prerenal azotemi, HRS ve akut tübüler nekrozdur. En çok görülen komplikasyonun ise $\% 38,1$ oranla HRSABH olduğu belirlenmiştir (7). Başka bir araştırmada ise HRS'li hastaların hastanede ölüm oranının \%66,3 olduğu bildirilmiştir (8). HRS'si olan 2.542 hastanın dahil edildiği bir araştırmada hastaların ölüm oranı \%37 olarak bildirilmiştir. Glomerülonefrit, ilaç toksisitesi ve abdominal kompartman sendromu da karşılaşılan komplikasyonlar arasındadır (9).

Böbreklerde yapısal bir sorun olmamakla birlikte azotemi, oligüri, glomerüler filtrasyon hızının azalması ve önlenemeyen assit birikimi tablosuyla HRS ortaya çıkmaktadır $(1,10,11)$. HRS, sirozlu ve assit birikimi olan hastalarda karaciğer işlevlerinin bozulmasından kaynaklanan, renal kan akımının azalması ile karakterize fizyopatolojik sürecin son aşaması olarak da düşünülmek- tedir. Ayrıca $\mathrm{ABH}$ ve dirençli assit birikimi (tedavi ile giderilemeyen, giderilse de hizla tekrarlayan assit birikimi) olan siroz hastalarında akut böbrek yetmezliğinin yaklaşık \%11'ini oluşturan yüksek mortalite oranına sahiptir (12). Karaciğer transplantasyonu yapılan hastalarda, ameliyat sırasinda yetersiz perfüzyon, ameliyat sonrasında ise hipovolemi ve ilaçlara bağlı görülen nefrotoksisite nedeniyle gelişen akut tübüler nekroz, transplantasyon sonrası böbrek yetmezliğinin önemli nedenleri arasındadır $(1,5$, 13,14). Akut böbrek hasarı, akut dekompansasyon dönemi sonrası sağlık kuruluşuna başvuran sirozlu hastaların \%25-50'sinde gelişebilmektedir (4). Bu hastalar; mevcut akut böbrek yetmezliği, şiddetli portal hipertansiyon ve dolaşım bozukluğu nedenleriyle en kötü prognoza sahip hastalardır $(12,15)$.

Çoklu organ hasarı olan, tip I HRS'li hastalarda, yoğun bakım ünitesinde üst düzey bakım ve izlem gerekmektedir. Hepatorenal sendrom gelişimini engellemek için en önemli girişim ise hasta izleminin düzenli ve dikkatli yapılmasıdır (3). Tan ve ark.'nın (2015) yaptığı meta analizde, karaciğer transplantasyonu sonrasında HRS hastalarının \%80'inin geri döndürülebilir olduğu bildirilmiştir. HRS'nin erken dönemde tespit edilmesinin hastaların sağ kalım oranlarını artırdığ ve ameliyat sonrası çıktılarını olumlu yönde etkilediği bulunmuştur (16). Bir diğer araştırmada ise; karaciğer transplantasyonu öncesi tip 2 HRS 
tanıs1 olan hastalarda olmayanlara göre, ameliyat sonras1 yoğun bakımda ( $6.4 \pm 1.2$ gün) ve hastanede kalış sürelerinin (21.0 \pm 2.4 gün) daha uzun olduğu saptanmıştır (17). Bu bağlamda, yoğun bakım ve transplantasyon ünitelerinde yatan hastaların izleminde hemşirelere önemli sorumluluklar düşmektedir. Bu nedenle, bu özellikli birimlerde çalışan hemşirelerin HRS tanı kriterleri, laboratuvar bulguları ve prognozu hakkında bilgi sahibi olmaları hayat kurtarıcı olabilmektedir.

$\mathrm{Bu}$ derlemenin amac1, yoğun bakım ve transplantasyon ünitelerinde, hepatorenal sendrom riski bulunan hastaların hemşirelik bakımında dikkat edilmesi gereken noktalara 1şık tutmaktır.

\section{Hepatorenal Sendromda Fizyopatoloji}

Hepatorenal sendromda görülen renal işlev bozukluğunun fizyopatolojisinde, ileri portal hipertansiyon ve dolaşım bozukluklarının, sistemik hemodinami üzerine etkileri mevcuttur $(18,19)$. Portal kan damarlarında gelişen portal hipertansiyon, damar endotelinin lokal etkili vazodilatör ajanlar üretmesine neden olur. $\mathrm{Bu}$ vazodilatör ajanlar, splenik damarlar üzerinde bölgesel ve şiddetli vazodilatasyona yol açar (20). Ortalama arter basıncinda meydana gelen düşüş, hemodinamik stabilitenin sağlanması ve kalp debisinin arttırılması amaciyla reninanjiyotensin-aldosteron sistemi ve sempatik sinir sistemini aktive eder. Vazopressin ve aldosteron, vücutta su ve sodyum tutulumunu arttırarak assitin daha da kötüleşmesine neden olur. $\mathrm{Bu}$ durumda, böbreklere giden kan akımının azalmasıyla birlikte HRS ortaya çıkar (Şekil 1) $(2,18)$. Güncel kılavuzlarda dolaşımdaki artan proinflamatuar sitokin ve kemokin seviyelerinin de HRS gelişiminde doğrudan rol oynayabileceği belirtilmektedir (21). Literatürde, ABH olmayan dekompanse sirozlu hastalarla prerenal azotemiye sekonder ABH'si olan hastaların karşılaştırıldığ bir çalışmada, ABH-HRS'li hastalarda proinflamatuvar sitokinlerin (interlökin-6, tümör nekroz faktörü- $\alpha$ ve interlökin-8) plazma konsantrasyonlarını arttığı saptanmıştır (22).

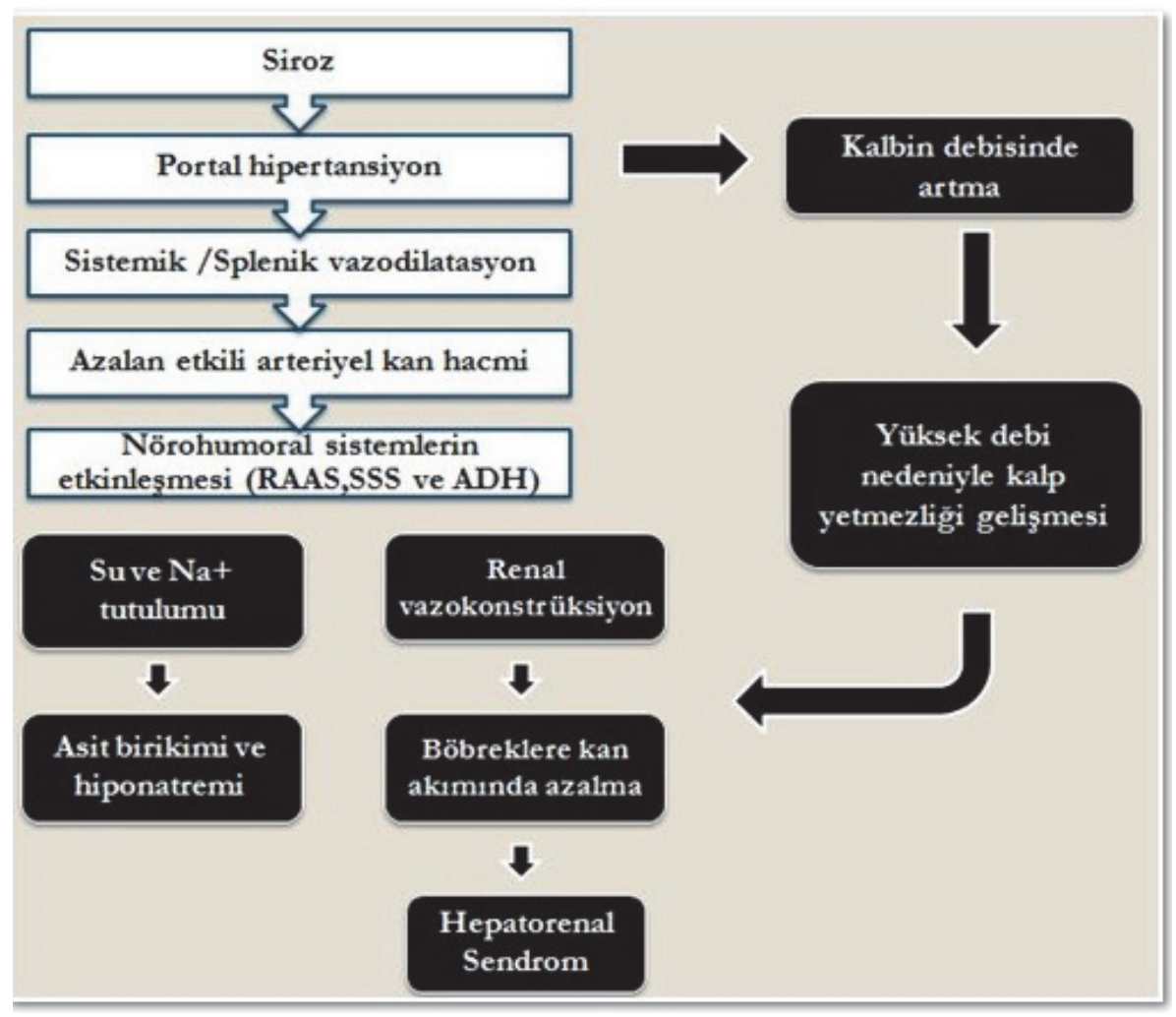

Şekil 1. Hepatorenal sendromun fizyopatolojisi $(2,18)$ RAAS: Renin-angiotensin-aldosteron sistemi SSS: Sempatik sinir sistemi ADH: Antidiüretik hormon 
Hepatorenal sendromun iki tipi bulunmaktadır. Daha önce yapılan sinıflandırma Tip I ve Tip II HRS olarak yer almaktaydı fakat güncellenen literatürde yeni sinıflandırma HRS-ABH ve HRS-ABH'nin olmaması (Non-Acute Kidney Injury- NAKI/NABH) şeklindedir (12,23). HRSABH tanı kriterleri; 48 saat içinde serum kreatin seviyesinde $(\mathrm{sCr}) \geq 0,3 \mathrm{mg} / \mathrm{dl}$ 'de mutlak artış, idrar çıkışının 6 saat ve üzerinde $0,5 \mathrm{ml} / \mathrm{kg} /$ saat'in altında olması veya taban değer olarak üç ay içinde ayakta tedavideki sCr'nin mevcut son sCr değeri üzerinden artışın \%50'den fazla olmasidır (23). HRS-ABH, sCr'nin 2,5 mg/dL'nin altında olduğunda da teşhis edilebilmektedir (24). HRS-ABH kriterlerini karş1lamayan sirozlu hastalarda fonksiyonel böbrek hasarı, HRSNABH olarak adlandırılır ve serum kreatininden ziyade tahmini glomerüler filtrasyon hızı (eGFR) ile tanımlanır. NABH, üç aydan daha kısa süreyle eGFR $60 \mathrm{~mL} / \mathrm{dak} / 1,73 \mathrm{~m}^{2}$, den az ise HRS-ABH ve üç ay ve daha fazla süreyle eGFR 60 $\mathrm{mL} / \mathrm{dak} / 1,73 \mathrm{~m}^{2}$ ise HRS kronik böbrek hastalı̆g 1 (HRS-KBH) olarak ikiye ayrı1ır $(21,23)$.

Hepatorenal sendrom için risk faktörleri; spontan bakteriyel peritonit, steroid olmayan anti-inflamatuar ilaçlar (NSAIİ), diğer nefrotoksik ilaçlar, intravasküler kontrast madde uygulaması, özofagus varis kanamaları, transjuguler intrahepatik portosistemik şant (TIPS) sonrası sendrom gelişimi olarak sıralanabilir (3).

\section{Tanı Kriterleri}

Hepatorenal sendromda, belirti-bulgular ve risk faktörlerinin bilinmesi ile hastaya en doğru tedavi ve bakım hizmetlerinin sunulması mümkündür. HRS için özellikle belirtilen bir tanı kriteri bulunmamakla birlikte, Uluslararası Assit Kulübü (International Club of Ascites-ICA) ileri evre sirozu olan hastalarda hepatorenal sendrom tipi $\mathrm{ABH}$ tanı kriterlerini aşağıdaki gibi belirlemiştir (12,23):

> Siroz; akut karaciğer yetmezliği; akut-kronik karaciğer yetmezliği

> Uluslararası Assit Kulübü kriterine göre; serum kreatinininde 48 saat içinde $\geq 0,3 \mathrm{mg} /$ dl veya başlangıç değerinden $\geq \% 50$ artış ve/veya idrar çıkışı $0,5 \mathrm{ml} / \mathrm{kg} / \mathrm{saat}, \geq 6$ saat
En az iki gün süresince diüretik verilmemesi ve albümin ile hacim genişletme sonrasında ICA kriterine göre tam veya kısmi yanıt yoksa; önerilen albümin dozu günde $1 \mathrm{~g} / \mathrm{kg}$ vücut ağırlığı ile maksimum 100 g/gün arasındadır.

Şok gelişmemiş olması

Yakın zamanda nefrotoksik ilaç kullanımının olmamas1 (NSAIII, aminoglikozitler, iyotlu kontrast madde vb.)

Yapısal böbrek hasarına dair aşağıda yer alan bulguların olmamas1;

○ Proteinüri ( $>500 \mathrm{mg} /$ gün proteinüri)

$\circ$ Mikrohematüri (> 50 eritrosit)

○ Üriner yaralanma biomarkerları (mümkünse)

- Renal ultrasonografide anormal bulgulardır.

\section{Hepatorenal Sendromda Tedavi}

Hepatorenal sendrom tedavisinde amaç; splenik ve sistemik vazokonstrüksiyonu düzeltmek, böbreklerin vazodilatasyonunu sağlamak ve sodyum dengesi sağlanan hastalarda normovolemiyi sürdürmektir $(12,25)$. Tedavi seçenekleri hastanın akut böbrek hasarı derecesine göre değişir. Algoritma Evre 1 ve Evre 2-3 olmak üzere iki gruba ayrilır (Şekil 2) (12):

- Aşama 1: Serum kreatinin düzeyinde $0.3 \mathrm{mg} / \mathrm{dl}$ ve üzerinde artış veya serum kreatinin düzeyinin bir buçuk kat ve üzerinde artış götsererek, olması gereken asgari düzeyin iki katına kadar artmış olması

- Aşama 2: Serum kreatinin düzeyinin iki kat ve üzerinde artış göstererek, olması gereken asgari düzeyin üç katına kadar artmış olması

- Aşama 3: Serum kreatinin düzeyinin olmasi gereken asgari düzeyin üç katına kadar artmış olması ya da akut olarak $0.3 \mathrm{mg} / \mathrm{dl}$ ve üzerinde artış göstererek, serum kreatinin düzeyinin 4 $\mathrm{mg} / \mathrm{dl}$ ve üzerinde olması ya da renal replasman tedavisine başlanmasıdır. 


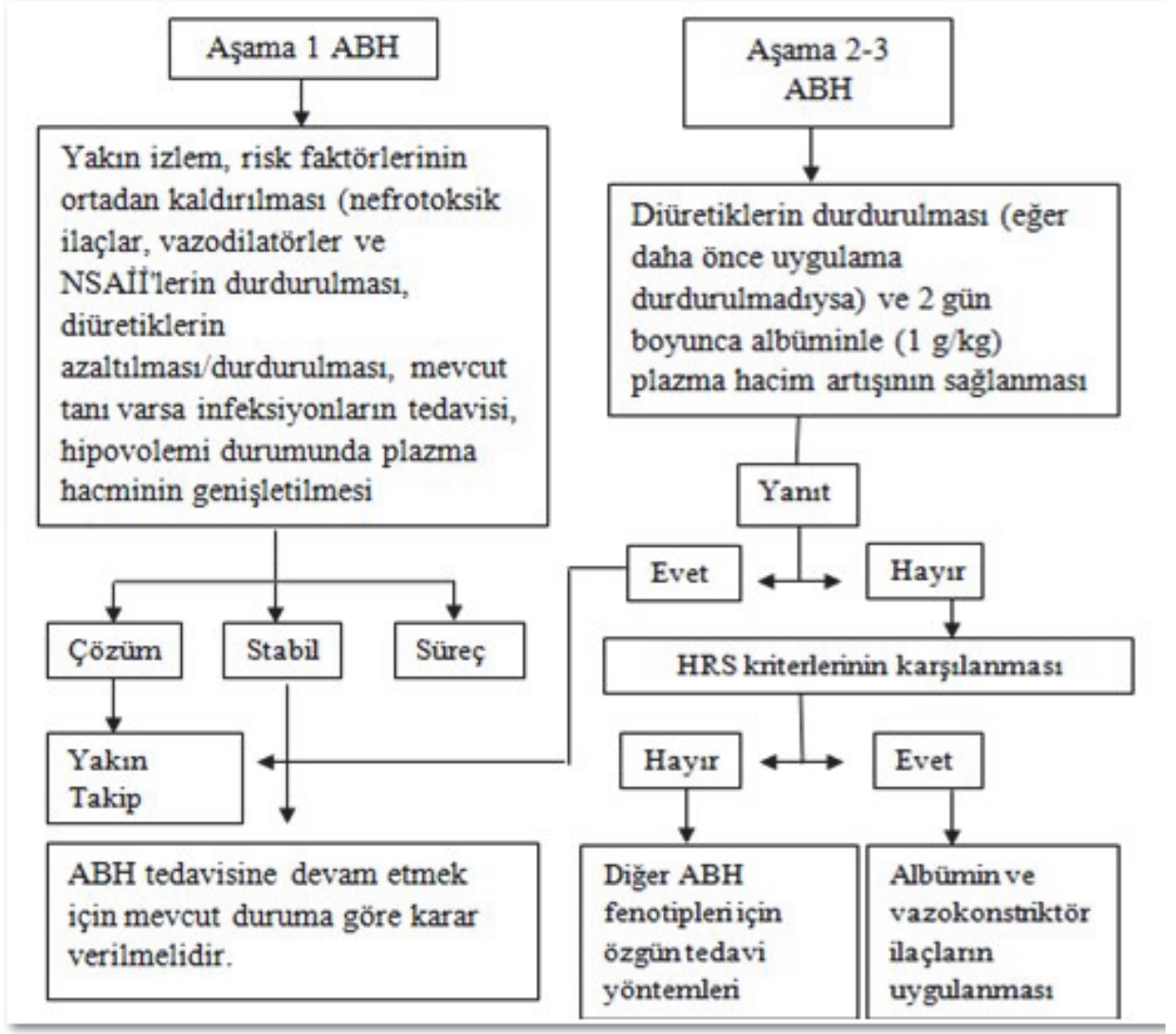

Şekil 2. Uluslararası Assit Kulübü - ABH (ICA-ABH) sinıflamasına göre akut böbrek hasarının $(\mathrm{ABH})$ yönetimi için önerilen algoritma (12)

\section{Tedavi Seçenekleri}

Vazokonstrüktör tedavi: HRS-ABH'nin tanı kriterlerine göre ABH 2. ya da 3. evrede yer alan hastaların intravasküler albümin ve vazokonstrüktör ilaçlarla tedavi edilmeleri önerilmektedir (12, 26). HRS-ABH 2. ve 3. evrede olan tüm hastalarda vazokonstrüktör ve albümin kullanılabileceği ayrıca hızlı bir șekilde de tedavi planı oluşturulması önerilmektedir (Kanıt seviyesi: III, güçlü öneri). Terlipressin ve albümin, HRS-ABH tedavisi için birinci basamak tedavi seçeneği olarak düşünülmelidir. Telipressin, her 4-6 saatte bir 1 mg'lık başlangıç dozunda intravenöz bolus olarak kullanılabilir (Kanıt seviyesi: I, güçlü öneri). Telipressine alternatif olarak noradrenalin de kullanılabilir (Kanıt seviyesi: I, zayıf öneri). $\mathrm{Bu}$ ilaçların kullanımı dolaşım yüklenmesi ve kardiyovasküler iskemi gelişmesine neden olabilmektedir. Bu yüzden hastaların tedavisine başlamadan önce kardiyogramı içeren izlemlerinin yapılması önerilmektedir (Kanıt seviyesi: I, güçlü öneri) (21).

\section{Transjuguler İntrahepatik Portosistemik Şant}

(TIPS): Bu yöntemde amaç, splenik dolaşımdan sağ kalbe venöz dönüşü arttırarak, portal basıncı ve peritoneal boşluğa filtrasyonu, lenfatik sistem tarafindan boşaltılabilecek bir seviyeye düşürmektir $(3,27)$. Bu nedenle, TIPS assit oluşumuna yol açan mekanizmaları ortadan kaldırabilir. TIPS, portal hipertansiyonu azaltan ve kardiyak debiyi arttıran bir tedavi yöntemidir. Vazokonstrüktörlere kısmi yanıt veren veya hiç yanıt vermeyen hastalar TIPS ile tedavi edilebilir $(4,12,19,26,27)$. Yapılan bir meta analizde; $\mathrm{sCr}$, kan üre nitrojeni, serum sodyumu, idrarla atılan sodyum ve idrar hacmi dahil olmak üzere neredeyse tüm böbrek fonksiyonu parametrelerinin TIPS'ten sonra önemli ölçüde iyileştiği saptanmıştır. Aynı çalışmada, TIPS uygulamasından sonra hastalarda görülen komplikasyon oranı 
\%31 bulunmuştur. Ayrıca HRS'li hastaların majör ölüm nedenlerinin de septisemi ve karaciğer yetmezliği olduğu saptanmıştır (28).

Yoğun bakım hemşirelerinin TIPS girişiminden önce ve sonra bazı sorumlulukları bulunmaktadır. TIPS girişiminden önce; hasta ve ailesine işleme yönelik bilgi verilmeli, hastanın 6-8 saat kat1 ve sıv1 alımı durdurulmalı, hastanın nörolojik durumu değerlendirilmeli, vücut sıcaklığ 1 ve solunum sayısı gibi yaşamsal bulguları izlenmeli, alerjisi sorgulanmalı, hastanın trombosit sayısına ve INR düzeyine bakılmalıdır (trombosit sayısının 60.000 'den fazla ve INR'nin 1.4'ten az olmas1 önerilir). TIPS girişiminden sonra; yaşamsal bulgu izlemi yapılmalı, girişim öncesi yaşamsal bulguları ile karşılaştırarak hastanın durumu değerlendirilmeli, kanama gibi komplikasyonların sebep olabileceği hemodinamik değişiklikler izlenmeli, ağrısı değerlendirilmeli, ateş gibi enfeksiyon belirti ve bulguları izlenmeli, hiperbilirubinemi ve hemolitik anemi (girişimden 7-10 gün sonra daha sik görülmektedir) gibi komplikasyonlar açısından hasta izlenmelidir (29).

Ekstrakorporeal karaciğer destek tedavisi: $\mathrm{Bu}$ tedavi yönteminde amaç, karaciğerin detoksifikasyon işlevini yerine getirmektir $(3,12,19)$. İki ana ekstrakorporeal karaciğer destek türü vardır: 1) tamamen detoksifikasyon cihazları (yapay) ve 2) hastanın bazı detoksifikasyon ve sentetik ihtiyaçlarını karşılayabilen fonksiyonel biyolojik aktivite sağlamak için cihaza hepatositleri dahil eden cihazlar (biyolojik). En iyi çalışılmış yapay ekstrakorporeal karaciğer destek cihazları albümin diyalizi ve plazma değişimi prensiplerine dayanmaktadır (30). Bu işlemler, moleküler resirkülatör emici sistemi (MARS) ve fraksiyone plazma ayrışması ve absorbsiyonudur (Prometheus) (30). Renal replasman tedavisiyle, suda çözünen toksinler vücuttan atılabilirken, karaciğer yetmezliği nedeniyle vücutta biriken birçok molekül albümine bağlanır ve diyaliz işlemiyle vücuttan atılamaz. Karaciğer destek tedavisi, suda çözünen bu toksinlerin vücuttan atılmasını hedeflemektedir (3).

Moleküler resirkülatör emici sistemi (MARS): $\mathrm{Bu}$ sistem, hastanın kanındaki albümini diyaliz çözeltisinden ayıran bir albümin geçirmez membrandan oluşur $(12,19)$. Sistem, karaciğer işlevlerinin devamlılığını sağlamak ve organ hasarını iyileştirmek amacıyla, albümine bağlı toksinlerin (safra asitleri ve nitrik oksit) ve suda çözünebilen sitokinlerin (IL-6 ve TNF-a) uzaklaştırılmasını hedeflemektedir (3).

Fraksiyone plazma ayrışması ve absorbsiyonu (Prometheus): $\mathrm{Bu}$ sistemde, fraksiyonlu plazma ayrıştırma ve absorbsiyon (FPSA) sistemi kullanılarak, albümine bağlı toksinlerin ve suda çözünebilen moleküllerin birlikte çıarılması amaciyla, birincil devrede plazma filtresi ve diyalizör ile ikincil devrede bilirubini çıkarmaya yarayan absorban filtreleri içermektedir. Böylelikle, plazma absorbsiyon yoluyla albümine bağl1 toksinlerden ve diğer tüm suda çözünebilen moleküllerden arındırılır (3).

Renal replasman tedavisi: Hepatorenal sendrom gelişen hastalarda (özellikle Tip I HRS), su ve sodyum tutulumu ya da üremik toksikasyondan dolayı metabolik asidoz veya hiperkalemi nedenleriyle diyalize ihtiyaç duyulabilmektedir $(3,20)$.

Karaciğer transplantasyonu (KT): Hepatorenal sendrom gelişen ve dekompanse siroz hastalar1nın medikal tedaviye yanıtına bakılmaksızın, karaciğer transplantasyonu en iyi tedavi seçeneği olarak karşımıza çıkmaktadır (Kanıt seviyesi: I, güçlü öneri) (16,21). Yapılan bir meta-analiz çalışmasında, karaciğer transplantasyonu sonrası, hepatorenal sendromu olan hastaların yaklaşık \%83'ünde belirtilerin normale döndüğü bildirilmiştir (16).

Karaciğer transplantasyonu, son dönem karaciğer hastalığ1, hepatoselüler karsinom (HCC) gelişen, akut karaciğer yetmezliği, sirozu olan hastalarda endikedir. Ülkeler arasında oranlar farklılık göstermekle birlikte akut karaciğer yetmezliğinin en yaygın nedenleri; virüsler (özellikle hepatit A ve B virüsleri), ilaçlar (asetaminofen) ve toksik ajanlardır. Varis kanamas1, assit, HRS ve ensefalopati gibi sirozun majör komplikasyonları ortaya çıktığında hastalar karaciğer nakli için değerlendirilmeli ve nakil merkezine sevk edilmelidir (Kanıt seviyesi: II) (31).

\section{Hepatorenal Sendromu Önlemeye Yönelik Girişimler}

Hepatorenal sendrom gelişimini önleme stratejileri; hastada karaciğer hastalığının ilerlemesinin önlenmesi, ilerlemiş sirozu olan hastalarda assit 
ve portal hipertansiyonun en iyi şekilde yönetilmesi, ABH'yi şiddetlendirdiği bilinen nefrotoksik ajanlardan ve beta blokerlerden kaçınılması, dolaşımı olumsuz etkileyen ve böbrek perfüzyonunu azaltan faktörlerin önlenmesidir $(3,29)$. Ayrica adrenal yetersizlikler tanımlanmalı ve tedavi edilmeli, böbrek fonksiyonlarının durumuna göre ilaç dozu ayarlaması yapılmalıdır (3). Özellikle spontan bakteriyel peritonit, varis kanaması ve nefrotoksik ilaç kullanımı gibi durumların önüne geçilmesi HRS riskini azaltmaktadır $(3,21)$ Güncellenen k1lavuzda HRS gelişmesini önlemek için öneriler bulunmaktadır. Kılavuzda; spontan bakteriyel peritonit ile başvuran hastaların intravenöz albümin ile tedavi edilmesi, HRS insidansını azalttığı ve sağ kalımı iyileştirdiği belirtilmektedir (Kanıt seviyesi:1, güçlü öneri). Ayrıca HRS-ABH gelişimini önlemek için spontan bakteriyel peritonit profilaksisinde Norfloksasin (400mg/gün) ve albümin kullanımı önerilmektedir (Kanıt seviyesi:1, güçlü öneri) (21).

\section{HEMȘIRELİK BAKIMI}

Hepatorenal sendrom sürecinin yönetiminde; diüretiklerin kullanımı, hipovoleminin düzeltilmesi, spontan bakteriyel peritonit gelişimi yönünden riskli olan hastalara antibiyotik profilaksisi uygulanması, albümin ve antibiyotik tedavisine başlanması öne çıkan uygulamalardır (29).

Yoğun bakım ve transplantasyon hemşiresi; hemodinamik durumu izlemek, belirlenen tedavi ve bakımı uygulamak, hastayı sik aralıklarla değerlendirmek ve klinik tablodaki değişiklikleri sağlık ekibine bildirmekten sorumludur. Bu sorumluluklarını yerine getirirken; hastayı ve hastalık sürecini anlayarak hastaya yaklaşmalı, etkili tanılama yapabilmek için de kanıta dayalı uygulamalardan ve klinik deneyimlerinden faydalanmalıdır $(1,5,11,14)$. Böylelikle hemşireler assit birikimi, ödem, idrar çıkışında azalma, $\mathrm{sCr}$ değerinde artma ve hemodinamide bozulma gibi hastayı olumsuz etkileyen etmenlerin HRS gelişimi ile ilişkisinin farkında olacaktır. HRS gelişmesi durumunda ise nefrotoksik (aminoglikozidler, kalsinörin inhibitörleri ve steroid olmayan antienflamatuvar ilaçlar, radyokontrast maddeler gibi) ilaçların ve yaşamsal önemi olan organlara (Ör: böbrek) kan akışının azalmasına neden olan beta bloker kullanımından kaçınılması gerektiğini bilerek duruma yaklaşmalıdır $(1,5,11$, 14,21).

Hepatorenal sendrom gelişen bireyin hemşirelik bakımında dikkat edilmesi gereken unsurlar; hastanın monitörize edilmesi ve sik aralıklarla izleminin yap1lmas1, sivi-elektrolit dengesini sürdürmeye yönelik önlemler alınması, beslenme ve günlük vücut ağırlığı izleminin yapılması, laboratuvar bulgularının izlenmesi, enfeksiyon ve peritonit gelişimi yönünden izlenmesi, cilt ve mukoza bütünlüğünün değerlendirilmesi, düşmeleri önlemeye yönelik önlemler alınması, hasta ve ailesine psikososyal destek sağlanması başlıkları altında incelenmiştir.

\section{Hasta monitörize edilmeli ve sık aralıklarla} yaşamsal bulgu izlemi yapılmalı: Kalp atım hızı, ritmi ve kan basıncı ölçülmeli, yaşamsal bulgular sık değerlendirilmeli ve gelişen değişiklikler anında belirlenmelidir $(1,33,35)$. Santral venöz basıncın ölçümü veya kan hacmini değerlendirmeye yönelik diğer ölçümler, sıvı dengesini optimize ederek dolaşımın aşırı yüklenmesini önlemeye yardımcı olabilir (Kanıt seviyesi: I) (21). Literatürde konu ile ilgili yapılan bir çalışmada, ilerlemiş siroz ve assit birikimi olan hastalarda, böbrek yetmezliğine bağlı olarak kardiyak sistolik işlev bozukluğu geliştiği bildirilmiştir (35).

\section{Hastanın sıvı-elektrolit dengesini sürdürmeye} yönelik önlemler alınmalı: Hastanın sıvı dengesi değerlendirilmeli, sıv1 alımının azalmasına bağlı gelişebilecek hipovolemi ve dehidratasyon belirtileri izlenmelidir. İdrar miktarı izlenmeli ve $<0,5 \mathrm{ml} / \mathrm{kg} / \mathrm{saat}$ ise dikkatli olunmalıdır (36). Siv1-elektrolit dengesi, böbreklerin normal işlevleri ile ilgili önemli bir belirteç olduğu için yakından izlenmelidir. Arteriyel kan gazı değerleri, asit-baz dengesizliklerinin göstergesi olabileceğinden dikkatle değerlendirilmeli, ensefalopati gelişme riskine karşın serum amonyak düzeyleri ve tüm elektrolit değerleri yakından izlenmelidir. Hastaya intravasküler sıvı desteği ve/veya albümin uygulanacaksa aşırı sıvı yüklemesini önlemek için infüzyon hızı ayarlanmalı ve boyun venlerinde dolgunluk, kalp seslerinde değişiklik, solunum güçlüğü gibi hipervolemi bulgularının varlı̆ğ değerlendirilmelidir. Assit 
birikimi olan hastaların karın çevresi günlük olarak ölçülmeli ve kaydedilmelidir. Her gün aynı yerden ölçüm yapılması için ölçüm yapılan hat işaretlenmelidir $(1,34,35,38,39)$.

Hastanın aldığı-çıkardığı tüm sıvılar dikkatli ve detaylı bir şekilde hesaplanmalı ve kaydedilmelidir. Hastanın çıkardığı sıvının hesaplanmasında idrar miktarı, sulu dışkı varlığı, kusma, dren ve fistüllerden gelen drenaj ile birlikte terleme nedeniyle kayıplar göz önünde bulundurulmalı, solunum şekli de dikkate alınmalıdır. En önemli elektrolit dengesizliklerinden biri olan hiperkaleminin, kas-iskelet ve kardiyak işlevleri etkilemesine ilişkin bulgular açısından hasta ve EKG izlenmelidir $(33-35,39,40)$

Hastanın beslenme ve günlük vücut ağırlığı izlemi yapılmalı: Hepatorenal sendrom gelişen bireylerde, hemodinaminin ve su-sodyum dengesinin sürdürülmesini sağlamak için sıvı kısıtlamasinı içeren az tuzlu (80-120 mmol/gün sodyum, yaklaşık 4.6-6.9 gr/gün tuz) diyet uygulanmalıdır $(34,41)$. Hastanın vücut ağırlığının izlemi her gün aynı saatte, aynı tartıda ve aynı kıyafetlerle yapılmalıdır (33-35,38). Bu süreçte, hastalarda ödem ve assit gelişebileceği için vücut ağırlığı ve albümin değerinin beslenmenin izleminde tek başına yetersiz kalacağ 1 unutulmamalı, alternatif olarak nutrisyonel risk skoru ve malnütrisyon evrensel tarama aracı gibi geçerli-güvenilir beslenme değerlendirme yöntemleri kullanılmalıdır (32).

Hastanın laboratuvar bulguları izlenmeli: HRS gelişme riski olan veya gelişmiş hastalarda; kan-üre nitrojeni (BUN), nötrofil, hemoglobin, hematokrit, kreatinin klirensi, bilirubin, albumin, sodyum ve potasyum düzeyleri günlük olarak izlenmeli, değişiklikler sağlık ekibiyle paylaşı1malıdır $(1,8,32,34)$. Yapılan bir araştırmada; HRS olan hastaların nötrofil oranının \%70'in üzerinde, $\mathrm{sCr} 1,27 \mathrm{mg} / \mathrm{dL}$ üzerinde ve ALT seviyesinin yüksek olmasının mortaliteyi arttırdığı saptanmıştır (8). Kullanılan ilaçların toksisite ve yan etkileri yönünden sik aralıklarla hasta ve laboratuar bulguları izlenmelidir $(1,34)$.

Hasta enfeksiyon ve peritonit gelişimi yönünden izlenmeli: Hepatorenal sendrom, assit birikimi olan sirozlu hastalarda ortaya çıkabilen spontan bakteriyel peritonitin, en ciddi kompli- kasyonu olarak da gelişebilmektedir. Hasta abdominal ağrı, vücut sıcaklığında yükselme gibi enfeksiyon belirti ve bulguları yönünden izlenmelidir. Klinik belirtiler olmadan da peritonit gelişebileceği göz önünde bulundurularak, kesin tanı amaciyla parasentez uygulaması gerekebilir. Antibiyoterapi, hem profilaksi hem de tedavi için uygulanabilmektedir (37). Antibiyoterapide norfloksasin uygulanmasinın, bir yıllık HRS ortaya çıkma olasılığını \% 41'den, \% 28'e düşürdüğü bildirilmiştir. Norfloksasin tedavisi ilerlemiş siroza bağlı gelişen HRS insidansını da azaltmaktadır (Kanıt seviyesi: 2B) (40). Nefrotoksisiteye neden olduğu bilinen antibiyotiklerden kaçınılmalıdır. Hastanın antibiyotiklere verebileceği alerjik yanıtlar dikkatle izlenmelidir. Hastane ilişkili enfeksiyonların gelişmesini önlemek için de gerekli önlemler alınmalı, kateter bakımında kanıta dayalı uygulamalardan oluşan bakım paketleri uygulanmalıdır (32). TIPS uygulamasından sonra şant giriş yeri, enfeksiyon belirti ve bulguları açısından değerlendirilmelidir. HRS tanı kriterleri arasinda sepsis durumunun olmaması yer almaktadır. $\mathrm{Bu}$ nedenle yoğun bakım ve transplantasyon birimlerinde çalışan hemşireler sepsis tanı kriterlerini bilmeli ve bu belirtiler açısından hastayı değerlendirebilmelidir.

Hastanın cilt ve mukoza bütünlüğü değerlendirilmeli: Vücudun sıv1 dengesinin bozulması, kan değerlerinde değişiklikler (albümin, hemoglobin vb) ve aktivite yetersizliği gibi nedenlerle hastaların cilt ve mukoza bütünlüğünde bozulma riski vardır $(1,42,43)$. Bu hastaların aktivite düzeylerinin belirlenmesi, hareketlilik ve pozisyon değişikliklerinin planlanması, beslenmesinin düzenlenmesi cilt bütünlüğünün koruması için oldukça önemlidir. Bireylerin kapsamlı bir cilt ve mukoza değerlendirmesinin yapılması, hareket ve aktivite düzeylerinin değerlendirilmesi için geçerli ve güvenilir risk değerlendirme skalalarının kullanılması önerilmektedir (Kanıt seviyesi: V). Basınç ülseri gelişme riski olan vücut bölümlerindeki basınç azaltılmalıdır (44). Ödeme bağlı gergin ve kuru olan cildin nemliliği sürdürülmelidir. Vücuttan atılamayan toksik metabolitler ciltte birikerek rahatsızlık verebilir bu nedenle, bireyin düzenli olarak cilt temizliği sağlanmalıdır. Cilt rengi, sıcaklığı ve nemliliği, dolaşım sorunların belirlenmesi için önemli birer göstergedir ve düzenli olarak izlemi yapılmalıdır 
$(1,42,43)$. Cilt tahrişini önlemek için sabun ve yapışkan bant kullanımından kaçınılmalıdır. Cilt irritasyonunu en aza indirmek için tahriş olmuş cilde losyon uygulanabilir $(37,44)$.

Düşmeleri önlemeye yönelik önlemler alınmalı: Akut süreçte hastada hepatik ensefalopati gelişmesi durumunda konfüzyondan komaya kadar bilinç değişiklikleri oluşabilir $(11,37)$. Ayrıca ilerlemiş karaciğer yetmezliğinde, hareketliliği kısıtlayan assit birikimi ve periferik ödem görülebilmektedir. $\mathrm{Bu}$ sebeplerden dolayı tüm hastalar düşme riski açısından değerlendirilmelidir (29). Hastaların yatak kenarlıkları kald1rılmalı, hasta ajiteyse bu yatak kenarlarına battaniye aracılığıyla yumuşak destekler oluşturulmalı, yatak frenleri kilitli tutulmalıdır. Hasta için güvenli bir bakım ortamı oluşturulmalı, yalnız bırakılmamalı, aileye yakın izlemin önemi, davranış ve bilinç durumu değişiklikleri hakkında bilgi verilmelidir (37).

Hasta ve ailesine psikososyal destek sağlanmalı: Hemşirenin en önemli rollerinden biri de hasta ve ailesinin eğitimini gerçekleştirmek, süreç boyunca bireylere destek olmak ve hasta bireyin savunuculuğunu yapmaktır. HRS, oldukça karmaşık bir süreçtir. Ayrıca hızlı gelişen bir süreç olması nedeniyle hasta ve ailesinde oluşan korku, yetersizlik duygusu, gergin yüz ifadesi, rahatsızlık ve kaygı bulguları değerlendirilmeli, duygularını ifade etmeleri için uygun ortam oluşturulmalı ve duygusal destek sağlanmalıdır. Tedavinin reddedilmesini ve sağlik çalışanlarıyla olası çatışmaları önlemek için hasta ve ailelerin uygun şekilde bilgilendirilmeleri gerekmektedir (45). Hasta ve aile üyelerinin, uzman psikolog, konsültasyon-liyezon psikiyatrisi hemşiresi, diyetisyen, vaka/durum yöneticileri, sosyal hizmet uzmanları veya terapistler gibi alanında uzman kişilere yönlendirilmesi, mevcut durumla başa çıkma sürecine yardımcı olabilir (37).

\section{SONUÇ}

Hepatorenal sendrom, karaciğerin işlev bozukluğuna bağlı bir dizi karmaşı hemodinamik ve nörohormonal değişiklikle tetiklenen, yaşamı tehdit eden bir komplikasyon olarak karşımıza çıkmaktadır. Özellikle karaciğer hastalığı olan bireyler, hastalığın erken belirtileri ve tanı konulabilmesi açısından dikkatle izlenmelidir. Yoğun bakım ve transplantasyon üniteleri gibi özellikli birimlerde görev yapan ve sağlik ekibinin vazgeçilmez bir üyesi olan hemşirelerin, HRS gelişen hastanın bakım sürecindeki başlıca sorumlulukları;

HRS izlemi açısından önemli olan laboratuvar bulgularını bilme

Hastalık seyrini olumsuz etkileyeceği bilinen nefrotoksik ilaç kullanımında dikkatli olma

HRS gelişiminin önlenmesi açısından enfeksiyon belirti ve bulgularını izleme

> Sepsis tanı kriterlerini bilme ve bu belirtiler açısından hastayı değerlendirebilme

Hastanın sivi-elektrolit dengesini ve özellikle diürez izlemini yapma

> Hemodinamiyi izleme

Gerekli tedavi ve bakımları uygulama

> Hasta ve ailesini bilgilendirme ve psikososyal destek sağlama

Hasta izleminde karşılaştığı değişiklikleri sağlık ekibi üyeleri ile paylaşmadır.

Özellikli birim hemşiresi, hastayı ve süreci anlayarak bakımı bütüncül yaklaşımla planlamalı, tedavi ve bakımın her aşamasında kanıta dayalı güncel bilgiler ile klinik deneyimlerini birleştirmelidir.

\section{Teşekkür/ Acknowledgements}

\section{Finansal destek}

Yazarlar herhangi bir finansal destek alınmadığını beyan etmişlerdir.

\section{Çıkar çatışması}

Yazarlar herhangi bir çıkar çatışması olmadığını beyan etmişlerdir.

\section{Hakemlik}

Çift kör hakemlik süreçleri uygulanmıştır.

\section{Yazarlık Katkıları}

Çalışma fikri ve tasarımı: PO, İK, SDÖ

Makalenin hazırlanması: PO, İK, SDÖ

Eleştirel inceleme: SDÖ, PO, İK 


\section{Kaynaklar}

1. Croghan A. Liver, Pancreas, and Biliary Tract Problems. Lewis S, Dirksen S, Heitkemper M, Bucher L, Harding M, eds. Medical-Surgical Nursing: Assessment and Management of Clinical Problems. 9th ed. Mosby Elsevier Inc; 2014. p.1006-1026.

2. Low G, Alexander GJM, Lomas DJ. Hepatorenal syndrome: aetiology, diagnosis, and treatment. Gastroenterology Research and Practice 2015;2015:1-11.

3. Baraldi O, Valentini C, Donati G, Comai G, Cuna V, et al. Hepatorenal syndrome: update on diagnosis and treatment. World Journal of Nephrology 2015;4(5):511.

4. Piano S, Rosi S, Maresio G, Fasolato S, Cavallin M, et al. Evaluation of the Acute Kidney Injury Network criteria in hospitalized patients with cirrhosis and ascites. Journal of Hepatology 2013;59(3): 482-489.

5. Altınbaş Y. Karaciğer Nakli ve Hemşirelik Bakımı. Çevik C, Özyürek P, eds. Organ Nakli Hemşireliği. 1. Baskı. İstanbul: Nobel Tip Kitabevi; 2017. s. 149-162.

6. Rey RM, Delgado AF, De Zubiria A, Pinto R, De la Hoz-Valle JA, et al. Prevalence and short-term outcome of hepatorenal syndrome: A 9-year experience in a high-complexity hospital in Colombia. PLoS One 2020;15(10):e0239834. doi: 10.1371/journal.pone.0239834.

7. Xiong J, Pu L, Xiong H, Xiang P, Zhang M, et al. Evaluation of the criteria of hepatorenal syndrome type of acute kidney injury in patients with cirrhosis admitted to ICU. Scand J Gastroenterol 2018;53(12):1590-1596. doi: 10.1080/00365521.2018.1545423.

8. Zhang S, He LL, Wang XH, Dang ZB, Liu XL, et al. A novel scoring model for predicting mortality risk in patients with cirrhosis and hepatorenal syndrome. Eur J Gastroenterol Hepatol 2018;30(8):938-943. doi: 10.1097/ MEG.0000000000001127.

9. Jamil K, Huang X, Lovelace B, Pham AT, Lodaya K, et al. The burden of illness of hepatorenal syndrome (HRS) in the United States: a retrospective analysis of electronic health records. J Med Econ 2019;22(5):421-429. doi: $10.1080 / 13696998.2019 .1580201$.

10. Lata J. Hepatorenal syndrome. World Journal of Gastroenterology 2012; 18(36): 4978.

11. Nowicki LV. Nursing Care of Patients With Liver, Pancreatic and Gallbladder Disorders. Williams LS, Hopper PD, eds. Understanding Medical Surgical Nursing. 5th Edition. Philadelphia: Davis Company; 2015. s. 780-809.

12. Angeli P, Ginès P, Wong F, Bernardi M, Boyer TD, et al. Diagnosis and management of acute kidney injury in patients with cirrhosis: revised consensus recommendations of the International Club of Ascites. Journal of Hepatology 2015;62(4):968-974.

13. Fisher EM, Brown DK. Hepatorenal syndrome. AACN Advanced Critical Care 2010;21(2):165-184.

14. Li G, Grant C. Hepatorenal syndrome: a nurse's guide to identification, management and advocacy. Gastrointestinal Nursing 2016;5(11):12-18.

15. Weil D, Levesque E, McPhail M, Cavallazzi R, Theocharidou E, et al. Prognosis of cirrhotic patients admitted to intensive care unit: a meta-analysis. Annals of Intensive Care 2017;7(33):1-14.

16. Utako P, Emyoo T, Anothaisintawee T, Yamashiki N, Thakkinstian A, et al. Clinical outcomes after liver transplantation for hepatorenal syndrome: a systematic review and meta-analysis. BioMed Research International 2018;2018:1-8

17. Tan HK, Marquez M, Wong F, Renner EL. Pretransplant Type 2 Hepatorenal Syndrome is associated with persistently impaired renal function after liver transplantation. Transplantation 2015;99(7):1441-6. doi: 10.1097/ TP.0000000000000557.

18. Davenport A, Sheikh MF, Lamb E, Agarwal B, Jalan R. Acute kidney injury in acute-on-chronic liver failure: where does hepatorenal syndrome fit? Kidney International 2017;92(5): 1058-1070.

19. Acevedo JG, Cramp ME. Hepatorenal syndrome: update on diagnosis and therapy. World Journal of Hepatology 2017;9(6): 293.

20. Ginès P, Schrier RW. Renal failure in cirrhosis. New England Journal of Medicine 2009;361(13):1279-1290.

21. European Association for the Study of the Liver. EASL Clinical Practice Guidelines for the management of patients with decompensated cirrhosis. Journal of Hepatology 2018;69(2):406-460. Doi: 10.1016/j.jhep.2018.03.024.

22. Solé C, Solà E, Huelin P, Carol M, Moreira R, et al. Characterization of inflammatory response in hepatorenal syndrome: Relationship with kidney outcome and survival. Liver International 2019;39(7):1246-1255. Doi: 10.1111/liv.14037. 
23. Angeli P, Garcia-Tsao G, Nadim MK, Parikh CR. News in pathophysiology, definition and classification of hepatorenal syndrome: A step beyond the International Club of Ascites (ICA) consensus document. Journal of Hepatology 2019;71(4):811-822. Doi: 10.1016/j.jhep.2019.07.002.

24. Simonetto DA, Gines P, Kamath PS. Hepatorenal syndrome: pathophysiology, diagnosis, and management. BMJ 2020;370:2687. doi: 10.1136/bmj.m2687.

25. Zeyneloğlu P. Hepatorenal sendrom. Türk Yoğun Bakım Derneği Dergisi 2012;10(1):37-44.

26. Colle I, Laterre PF. Hepatorenal syndrome: the clinical impact of vasoactive therapy. Expert Review of Gastroenterology \& Hepatology 2017;12(2):173-188.

27. Rossle M, Gerbes AL. TIPS for the treatment of refractory ascites, hepatorenal syndrome and hepatic hydrothorax: a critical update. Gut BMJ 2010;59(7):988-1000.

28. Song T, Rössle M, He F, Liu F, Guo X, et al. Transjugular intrahepatic portosystemic shunt for hepatorenal syndrome: A systematic review and meta-analysis. Digestive and Liver Disease 2018;50(4):323-330. Doi: 10.1016/j.dld.2018.01.123.

29. Kasper J, Bettinelli M. Care of the critically ill patient experiencing alcohol withdrawal and/or liver failure. Perrin Ouimet K, Macleod Edgerly C, eds. Understanding the Essentials of Critical Care Nursing. Third Edition. New York: Pearson; 2017.

30. Katarey D, Jalan R. Update on extracorporeal liver support. Current Opinion in Critical Care 2020;26(2):180-185. doi: 10.1097/MCC.0000000000000708.

31. EASL Clinical Practice Guidelines: Liver transplantation. J Hepatol 2016;64(2):433-485. doi: 10.1016/ j.jhep.2015.10.006.

32. Ayar Y, Ersoy A, Soyak H. Cirrhosis and renal dysfunction. Turkish Nephrology Dialysis Transplantation 2016;16:25.

33. Fitzpatrick E. Assessment and Management of Patients With Hepatic Disorders. Smeltzer SC, Bare BG. Brunner \& Suddarth's Textbook Of Medical Surgical Nursing. 2.nd ed. Philadelphia: North American Edition, Lippincott Williams\& Wilkins; 2010. p. 1116-1168.

34. Nowicki L. Nursing Care of Patients With Liver, Pancreatic, and Gallbladder Disorders. Williams L, Hopper P, eds. Understanding Medical Surgical Nursing. 5th ed. Philadelphia: F.A. Davis Company; 2015. p. 779- 808.

35. Kanan N. Sıvı-Elektrolit ve Asit-Baz Dengesizlikleri. Aksoy G, Akyolcu N, Kanan N, eds. Cerrahi Hemşireliği I. 1. Baskı. İstanbul: Nobel T1p Kitabevi; 2017. s. 49-77.

36. Krag A, Bendtsen F, Henriksen JH, Moller S. Low cardiac output predicts development of hepatorenal syndrome and survival in patients with cirrhosis and ascites. Gut BMJ 2009;59(01):105-110.

37. Metcalfe H. Assessment and Management of Patients With Hepatic Disorders. Farrell M, eds. Textbook of Medical Surgical Nursing. Fourth Australian and New Zealand Edition. Sydney: Lippincott Williams\&Wilkins Wolters Kluwers Health; 2017.

38. Tok Özen A, Enç N. The role of nurses for changes in fluid-electrolyte balance in critical diseases. Journal of Cardiovascular Nursing 2013;4(1):9-13.

39. Olgun N, Aslan FE, Fındık ÜY. Karaciğer Hastalıkları. Karadakovan A, Aslan FE, eds. Dahili ve Cerrahi Hastalıklarda Bakım. 4. Bask1. Ankara: Akademisyen Kitabevi; 2017. s.709-741.

40. EASL clinical practice guidelines on the management of ascites, spontaneous bacterial peritonitis, and hepatorenal syndrome in cirrhosis. Journal of Hepatology 2010;53(3):397-417. doi: 10.1016/j.jhep.2010.05.004.

41. Wadei HM, Mai ML, Ahsan N, Gonwa TA. Hepatorenal syndrome: pathophysiology and management. Clinical Journal of the American Society of Nephrology 2006;1(5):1066-1079.

42. Soyer Ö. Böbrek Nakli ve Hemşirelik Bakımı. Çevik C, Özyürek P, eds. Organ Nakli Hemşireliği. 1. Baskı. İstanbul: Nobel Tip Kitabevi; 2017. s. 149-162.

43. Karadakovan A, Kaymakçı Ş. Üriner Sistem Hastalıkları. Karadakovan A, Aslan FE, eds. Dahili ve Cerrahi Hastalıklarda Bakım. 4. Bask1. Ankara: Akademisyen Kitabevi; 2017. s. 857-915.

44. European Pressure Ulcer Advisory Panel and National Pressure Ulcer Advisory Panel. Prevention and treatment of pressure ulcers: quick reference guide. Washington DC: National Pressure Ulcer Advisory Panel; 2009

45. Hupcey JE. Feeling safe: the psychosocial needs of ICU patients. Journal of Nursing Scholarship 2000;32(4):361-367. 